UDC 159.922 .4

DOI: $10.52534 / \mathrm{msu}-$ pp.7(4).2021.76-85

\author{
Anzhelika V. Kolly-Shamne ${ }^{1^{*}}$, Aleksandras Patapas ${ }^{2}$ \\ ${ }^{1}$ Kryvyi Rih State Pedagogical University \\ 50086, 54 Haharin Ave., Kryvyi Rih, Ukraine \\ ${ }^{2}$ Mykolas Romeris University \\ LT-08303, 20 Ateities Str., Vilnius, Lithuania
}

\title{
Age Discrimination, Gerontostereotypes, and Gerontological Ageism: Cross-Cultural Aspect
}

\section{Article's History: \\ Received: 15.09 .2021 \\ Revised: 14.10 .2021 \\ Accepted: 18.11.2021}

\section{Suggested Citation:}

Kolly-Shamne, A.V., \& Patapas, A. (2021).

Age discrimination, gerontostereotypes, and gerontological ageism: Cross-cultural aspect. Scientific Bulletin of Mukachevo State University. Series "Pedagogy and Psychology", 7(4), 76-85.

${ }^{*}$ Corresponding author
Abstract. The intensive ageing of the population in all countries of the world creates problems of ageism, age discrimination, and biased attitude towards older people, which provoke considerable negative consequences both for representatives of this age and for society in general. The study of crosscultural aspects of these phenomena largely enriches their understanding and is directly related to the search for ways to prevent them in various cultural and socio-economic conditions. The purpose of the study was to theoretically analyse the problem of ageism as a form of age discrimination against older people, in particular its cross-cultural factors, features, and consequences. Methods of theoretical and meta-theoretical level (dialectical method and system analysis method) were used. The study identified key trends related to the ageing process of the entire population. The concept of "ageism" and its content were clarified, the specific features of the concept of "gerontological ageism", its components, factors and forms of manifestation were determined. Cross-cultural features of ageism manifestations as a form of age discrimination against older people in western and eastern, individualistic and collectivist cultures were considered. For this purpose, international theoretical and empirical models and programmes were analysed, as well as cross-cultural studies of ageism implemented in various cultural contexts (in the USA, Western and Eastern Europe, East Asia, Asia-Pacific region, etc.). The results obtained in the study are of practical importance since they indicate the possibilities of preventing gerontoageism in different countries and at different levels of social life, and above all the prospects for changing negative perceptions and stigmatising ageing in Ukrainian society

Keywords: gerontopsychology, cross-cultural psychology, stereotypes, ageism, old age, age discrimination, model of stereotype content, causes of gerontoageism

\section{INTRODUCTION}

The demographic phenomenon of intense population ageing and an increase in the proportion of older people is becoming a new historical experience of mankind. This creates new challenges, including the perception of old age and ageing and the expectations of older people. This new experience can cause negative attitudes towards older people, and stereotypes and biases associated with old age can lead to age discrimination (gerontological ageism). Old age in gerontopsychology is usually analysed in the aspect of problems of ontogenesis but increasingly attention is drawn to its cross-cultural and socio-psychological aspects, primarily in the context of the analysis of old age as the most important social marker that plays an important role in the processes of interaction of people and, in particular, acts as the basis for one of the types of social discrimination age discrimination against the elderly [1].

Discriminatory practices against the elderly as a social phenomenon have emerged in most countries of the world as a result of powerful social and technological transformations that have considerably changed the role 
and place of older people in society [2]. In modern Western countries, old age is often perceived as a period of negative age-related transformations, diseases, dependence, finiteness of life, uselessness, isolation [3-4], loss of autonomy and various types of deficits [5]. As noted by the French sociologist A. Langevin, old age as the age of life has a certain profile from one social class to another and from one gender to another but an ability to discriminate remains constant $[6$, p. 50]. The image of an elderly (and even more old) person is associated with particularly aggravating stereotypes and prejudice [7]. Therewith, it is often referred not to a clear violation of the rights of older people but an insult to their self-esteem (jokes about age, compliments about good appearance, surprise when voicing the actual age of the interlocutor, obsessive questions about health, pretentious congratulations on anniversaries, etc.) [8]. Even in the context of modern normative models of ageing (for example, the theory of successful/active ageing), the problem of discrimination against older people arises [9] since these models often do not consider the different reality of ageing, its heterochrony and heterogeneity [10]. They often tend to reduce ageing to a person's "individual responsibility", denying various social living conditions of older people related to gender, ethnicity, social class, sexual orientation $[9 ; 10]$.

According to the results of modern Russian [11-13] and Ukrainian [14-16] studies, it can be stated that in postSoviet societies, and Ukraine in particular, mostly negative images of old age and ageing predominate. In the eyes of young, older people are often associated with poor health, helplessness and social isolation, are perceived as unnecessary ballast, as a burden, as infirm and unnecessary members of society, there is a negative stereotyping of difficulties associated with old age as a period of loneliness, poverty, low social mobility, insolvency, and the need for care and support from state institutions. Distorted ideas, negative emotions, and beliefs of young people concerning elderly gradually develop into discriminatory actions [17]. For example, in a study by O.O. Berezina, $94.5 \%$ of respondents of pre-retirement and retirement age answered positively to the question about the signs of ageism on the part of society, of which more than $40 \%$ admitted that they often experience a negative attitude from the environment [14]. According to the study of N.M. Pecheritsa, gerontoageism of Ukrainian students can manifest itself in direct and indirect images of elderly people, in personal aversion to them, ridicule, hostility, biased attitude, disrespect, negative judgments, unwillingness to listen and cooperate, intolerance, indifference, avoidance of contacts (visual, tactile), in an aggressive attitude towards them [17]. As M.O. Ekimova notes, age discrimination "...permeates our lives more tightly than it seems at first glance" [18, p. 217]. A person may not get a chance to acquire a certain status and fulfill their role because their biological age is considered "inappropriate" in society. It is precisely this absolutisation of age stereotypes that is a social problem since it causes infringement of people's rights, increasing inequality, dysfunctions of social organisations and institutions [18, p. 223]. Notably, age and gender are the most frequently mentioned causes of discrimination in the EU [19].

In view of the above, the problem of cultural and historical manifestations and cross-cultural features of discriminatory practices against older people is extremely relevant both in terms of studying their causes and consequences. Ignoring the cross-cultural perspective in this issue leads to the fact that the scientific discussion of the problems of age discrimination against older people is limited to local research problems and does not form a logically consistent and internally structured scientific field. Scientific discussions and searches related to either societal or personal aspects of ageism problems do not contribute to an integrated generalisation of existing research. Accordingly, there are complications associated with systemic prevention of ageism in different countries and at different levels of social life. This raises the problem of determining the specific features of discriminatory attitudes towards old age, the ageing process, and the elderly as representatives of the age group in different cultural and socio-economic conditions.

The purpose of the study is a theoretical analysis of the problem of gerontostereotypes and gerontological ageism as forms of age discrimination of older people, in particular its cross-cultural factors, features, and consequences. The study sets out the following objectives: to identify the main trends associated with the ageing of the population around the world; to analyse the terminological field of the concept of ageism and gerontological ageism; to consider the problem of age discrimination based on old age in different cultures as a key issue, as well as the main international theoretical models of ageism research; to carry out a comparative analysis of the cross-cultural features of gerontological ageism in eastern and western, collectivist and individualistic countries, as well as to determine the causes of its occurrence and forms of its manifestation in different cultures

\section{GERONTOLOGICAL AGEISM AS A FORM OF AGE DISCRIMINATION, ITS MANIFESTATIONS AND CAUSES}

Ageism as a phenomenon of age discrimination and an interdisciplinary concept attracted attention only in the mid-1960s, when age discrimination became the object of scientific interest of sociologists and psychologists of the $20^{\text {th }}$ century. Prior to this, the main focus was on racism (mainly in the United States) and sexism [2; 20]. By analogy with racism and sexism in 1969, the American sociologist R.N. Butler suggested using the concept of ageism to denote age discrimination [21]. They defined the content of ageism as a combination of three interrelated elements: negative stereotypes of old age and ageing, discriminatory practices against the elderly in interpersonal interaction of people, as well as at the level of functioning of various public institutions [21, p. 243]. Later, A.J. Traxler considered ageism as any attitude, behaviour, or social institution that subordinates people based on age, as well as the process of assigning 
certain social roles to a person based on their age [22]. In the study of A.J.C. Cuddy and S.T. Fiske, this term refers to stereotypes and prejudices associated with representatives of a certain age group, leading to its discrimination [23]. Thus, ageism is stereotypes and discrimination against individuals or groups because of their age aimed at such age groups as adolescents, young people, and the elderly [1]. Ageism includes two main components: firstly, the ageist ideology of stereotypes and views, and secondly, age discrimination or behaviour that puts people at a disadvantage when compared with others, depending on their age [24;27].

Modern authors analyse ageism as a phenomenon that is represented at the interpersonal, intergroup, institutional, and cultural levels $[22 ; 25 ; 27]$. However, the key problem in the framework of socio-psychological studies of ageism was the study of age-related stereotypes that function in human interaction. At the same time, it is emphasised that modern studies of ageism are characterised by vague definitions of the concept of "ageism". In a considerable number of studies devoted to the study of the causes and consequences of ageism, there is no clear definition of this phenomenon. As a result, this area of research is characterised by extremely contradictory results that are difficult to verify and compare. Therefore, according to T.N. Iversen et al, it is extremely important to formulate a clear conceptual framework for studying this phenomenon [28].

"Ageism, like sexism and racism, is a biased behaviour of society towards older people or negative stereotypes about them" [29, p. 39]. Unlike race and gender, which are fixed at birth and are constant throughout life, old age is part of the life cycle of every person and everyone, sooner or later entering this last stage of life, can become an object of age discrimination. Thus, ageism as a form of discriminatory attitude towards old age is unique among "isms" because everyone ages over time, as a result of which most people experience ageism [20].

R.N. Butler described those main factors which lead to the emergence of gerontological ageism and contribute to the transformation of ageing from a natural process into a social problem that has harmful and destructive consequences for the elderly [30]. They noted that "there are three different but interrelated aspects of the problem of ageing":

1) biased attitudes towards older people, old age, and the ageing process, including the attitudes of older people themselves;

2) discriminatory practices against older persons, especially in employment or other social roles;

3) institutional practices and policies, which often without malicious intent perpetuate stereotypical ideas about older people, reduce their opportunities for a satisfactory life and undermine their personal dignity" [30].

Gradually, various methodologies and scales were used to study gerontoageism. Some of the most common are semantic differential scales that contain bipolar personality traits. They usually require the participant to indicate a trait that is more representative of the elderly person $[31 ; 32]$. However, the authors of the analytical review note the variability and inconsistency of the results obtained using this method [33]. Finally, in modern research, gerontological ageism is defined as discrimination, neglect, or the practice of humiliating human dignity, implemented based on negative age stereotyping, as well as negative age stereotypes themselves [34].

Manifestations of gerontoageism are diverse. Most often, ageism in society occurs in the form of negative personal interactions between representatives of other age groups and elderly people (lack of respect for old people, abusive behaviour towards them, manifestations of ill-will and aggression); in the form of disparaging statements about old age and old people (proverbs, sayings) and existing beliefs in society, based on outdated concepts of the period of late adulthood exclusively as a time of regression and decline (stereotyping, perception of people of post-retirement age as public ballast, etc.); in the indifferent attitude of medical personnel in polyclinics, sanatoriums, and hospitals for the elderly [35]. The older a person looks, the more manifestations of negative attitude on the part of others he has to meet. A manifestation of gerontoageism is also a type of discrimination such as social isolation, which often affects older people [36; 37]. A manifestation of a discriminatory attitude towards old age is also the lack of a tolerant attitude towards old age, the existence of stereotypes of old age, through the prism of which older people are perceived. Ageism aimed at the elderly is based on the belief that people older than a certain age have a lower status and role in society $[38$, p. 4$]$.

At the same time, it is noted that simultaneously with negative stereotypes, old age is endowed with positive traits $[35 ; 39 ; 40]$. In other words, the phenomenon of ageism can represent not only a negative but also a positive view of the problem of old age. The concept of positive and negative ageism was first introduced by E. Palmore in 1999 [20]. The author identified nine main stereotypes that reflect negative biases towards older people and eight main positive stereotypes that, in their opinion, are much less common [20] (Fig. 1). 


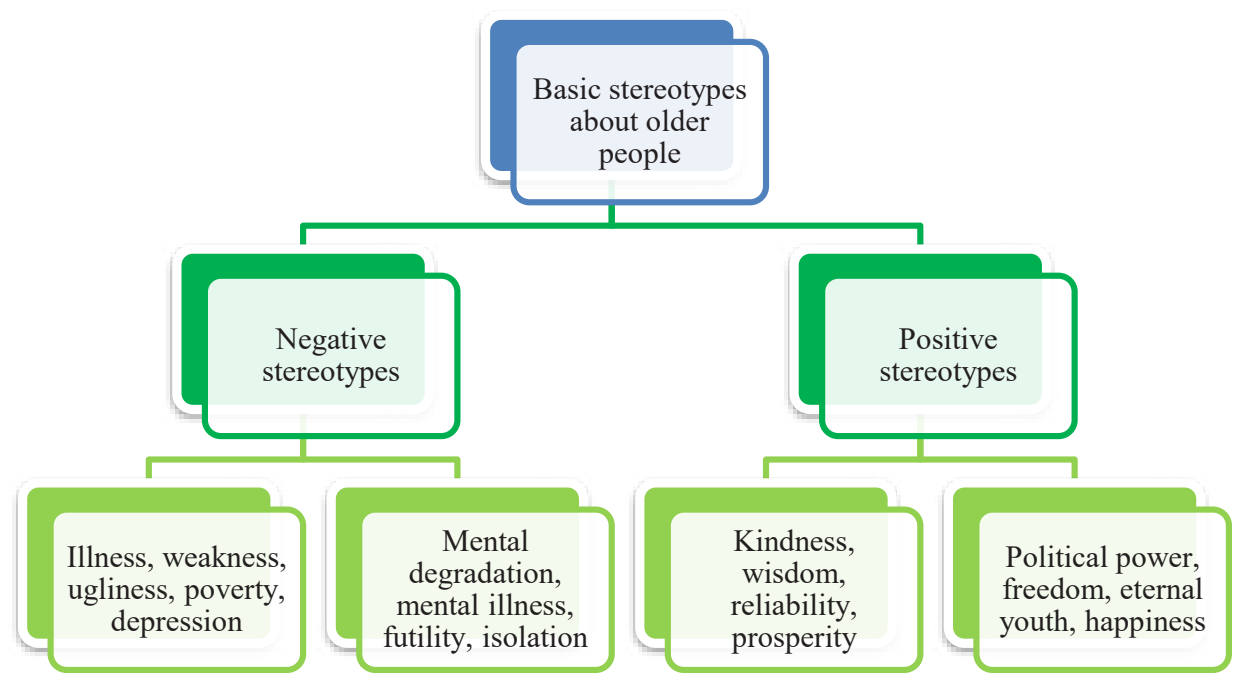

Figure 1. The main negative and positive stereotypes as a manifestation of positive and negative ageism according to E. Palmore

Cross-cultural studies of ageism are also aimed at identifying factors and causes of stereotyping and ageism among young people and adults in different countries. It is assumed that young people in all countries of the world acquire ageist habits and distance themselves from older people due to the fact that they associate old age with death and incompetence. Age, for example, is the biggest risk factor for the onset and development of dementia, so a large number of young people may be "afraid" of ADRD (Alzheimer's Disease and Related Dementias) because ageing is inevitable and older people are often associated with negativity and reduced cognitive function. In a study conducted in Ireland, P. McParland et al [41] identified negative attitudes towards people with dementia among adults of all ages. There was also a considerable likelihood of exacerbation of DRA (dementia-related anxiety), which can occur based on strong latent negative biases against older people [26], age-related cultural stereotypes [36], and dementia-related stigma [42; 43]. According to the micro-level theory of Terror Management Theory (TMT), older people serve young people as a reminder of their own vulnerability and mortality, respectively, in this way young people try to create a buffer that will mitigate and reduce their anxiety associated with death [2]. Thus, a large part of the negative attitude of young people to old age in many Western countries is associated with the cognitive abilities of older people, although this negative attitude can occur even with no signs of cognitive decline [26;36;44].

Another reason for age discrimination is that contacts between people over the age of 65 and young people or children in all countries of the world are becoming less frequent and less intense compared to the past [45]. The spatial and cultural distribution between these age groups leads to the emergence of intergroup negative emotions or ignoring, which contributes to the development of stereotypes and bias. Ageism aimed at the elderly also reinforces the belief that people over a certain age cause a higher economic burden on society, especially the working population, due to their increased consumption of medical and social services $[38 ; 46 ; 47]$. Based on cross-national surveys, L. Jurek traced the dynamics of ageism and negative attitudes towards older people in different European countries due to an increase in public spending on their maintenance (medical services, pension payments, long-term care,) [47]. In particular, the author identified that an increase in the number of hospital beds occupied by older people and medical consultations provided to them positively correlates with ageism [47]. The implementation of various pension programmes aimed at economic protection and improving the standard of older people's living increases the perception of older people as inappropriate, outdated, unnecessary, and unimportant [46].

\section{CROSS-CULTURAL FEATURES OF AGEISM IN WESTERN AND EASTERN, INDIVIDUALISTIC AND COLLECTIVIST CULTURES}

Studies have shown that persistent age stereotypes are common among different groups of people [26] and that ageism is characteristic of different countries and cultures [48-50]. Xue Bai states that when compared with older people, young and middle-aged people in all countries of the world, for the most part, have simpler, vague, and more negative stereotypes about older people [50]. However, their intensity in different countries (with some exceptions, for example, [51; 52]) remains uncertain [48; 53]. There are separate empirical studies of narrow issues, for example, cross-cultural comparison of views, attitudes, and preferences regarding elderly care among Australian and Chinese nursing students [54]. However, as the authors note, there are practically no systematic empirical comparisons between countries, which explains certain discrepancies in the obtained empirical results [49].

Studies of different age groups have documented conflicting results regarding differences in the level of ageism in different countries [49; 53; 55]. For example, most studies have reported that attitudes towards older people 
in individualistic countries (for example, the United States, Australia), as a rule, were more negative than in collectivist countries (for example, China, Malaysia, India) [48; 54]. This discovery was consistent with the idea that individualistic societies care less about older people, which can lead to neglect of them. Moreover, individualistic societies pay special attention to productivity in the workplace, which is less likely to be inherent in older people and can cause negative attitudes towards them [55]. However, a number of other studies have not found considerable differences in the level of ageism between individualistic and collectivist cultures [53].

Ageism has been studied in various cultural contexts, particularly in the United States [56], Europe [2; 49], and East Asia [36; 57]. These studies have shown that contrary to expectations, age-related stereotypes and discrimination spread not only outside the United States but also outside individualistic cultures in general, and are also widespread in collectivist countries in East Asia [36]. In the last quarter of the $20^{\text {th }}$ century, separate comparative studies were conducted in which respondents from the countries of the Asia-Pacific region showed an even more negative attitude towards older people than their American counterparts, in particular, this refers to studies conducted in China [58], Thailand [59], Japan [60], etc.

The study [39] analysed cultural differences in the age stereotypes of young and older people in American and Chinese cultures in two areas: socio-emotional and mentalphysical. Both young and elderly Chinese and American participants described "typical" young and "typical" older people. Then all responses were encoded by valency (positive-negative-neutral) and content (mental-physical, socialemotional, etc.). It occurred that in both cultures, stereotypes reflected a dynamic from more positive to more negative views on mental and physical qualities as a function of ageing. In the social and emotional spheres, stereotypes about older people were relatively neutral. The results showed that age perceptions of typical older adults are similar in East Asian and Western cultures, and that there is no global positive bias towards old age in East Asia. However, some differences were also found between Asian countries. The study [61] examined the differences between Japanese and Korean students' perceptions of older people (Japan and South Korea are the oldest societies in the world but Japan has a more developed social security system for older people than Korea). The five most common images among Korean students were mostly negative, while the most common images of Japanese participants were mostly neutral or positive. The results have also shown that young people's living with grandparents can lead to the development of a negative image of older people. According to the researchers, stereotypes of older people seem to be very stable, as well as cross-cultural, with equally negative views of older people in both individualistic and collectivist societies [36]. Therefore, the authors of some studies claim that stereotypes about older people are universal $[36 ; 50]$.
Among the largest European projects to study crosscultural aspects of ageism, the results of the fourth round of the European Social Study (ESS) (2008-2009), which aimed to study ageism, the experience of age discrimination and attitudes towards different age groups in 29 European countries, were indicative [49]. The authors concluded that ageism is a phenomenon that is present in both more and less individualistic societies and in different European countries. Age discrimination was highest in Eastern European countries (for example, the Czech Republic, Romania, Russia, Smination was recorded in the countries of Southern, Northern, and Central Europe (for example, Portugal, Cyprus, Denmark, Norway, and Switzerland) [49].

Another study of ageism in older people in $25 \mathrm{EU}$ countries was implemented based on data from the Special Eurobarometer N 437 survey conducted in 2015 as part of the European Eurobarometer programme (Eurobarometer the most up-to-date international database that includes information about ageism, as well as attitudes to sexism, racism, LGBT, etc. [62]). Ageism is considered by a Polish researcher who analysed the results of the Special Eurobarometer N 437 survey from three standpoints: a) perception of discrimination in general; b) age discrimination in difficult economic times; c) bias against high-level elderly officials [63]. Two-level regression allowed the author to simultaneously model the impact at both the individual and country levels to understand to what extent the variability of ageist statements is conditioned upon the sociocultural characteristics of the country, and to what extent it can be explained by individual differences. As a conclusion, personal characteristics influence ageism more than the context of the country. Women perceive ageism much more strongly than men. Most of all, people experience manifestations of ageism in pre-retirement age and in situations that reflect stereotypes about lower labour productivity of older people [63]. In terms of cross-cultural characteristics, the increase in age discrimination, according to Special Eurobarometer N 437, is most noticeable in all former socialist countries (Lithuania, Latvia, Romania, Bulgaria, Czech Republic and Slovakia, Slovenia), except Poland. Among Western countries, the highest level of ageism was recorded in France, Great Britain, and the Netherlands [63].

Most social psychologists recognise the primacy of social stereotypes regarding prejudice and discriminatory behaviour $[64 ; 65]$, so age stereotypes are often analysed as the psychological core of age discrimination. In particular, many studies are based on the SCM (Stereotype content Model) $[56 ; 66 ; 67]$ as a means of studying ageism. This stereotypical content model (SCM), proposed in 2002 [36; 66], presents a combination of negative and positive stereotypes. It is based on two parameters: warmth and competence. In a stratified society, competence as a personal trait (property) is usually attributed to people with a higher social position to justify their dominant status; the parameter "warmth" reflects such personal characteristics as softness, 
cordiality, sincerity. The SCM suggests that stereotypes can not only be classified into two dimensions (warmth and competence) but also analyse the combination of these dimensions, which creates four modalities: a) pity: high warmth + low competence; b) envy: high competence + low warmth; C) admiration: high warmth + high competence; d) contempt: low warmth + low competence (Fig. 2).

\begin{tabular}{|c|c|}
\hline \multicolumn{2}{|c|}{ Pity } \\
\hline High warmth & Low competence \\
\hline \multicolumn{2}{|c|}{ Admiration } \\
\hline High warmth & High competence \\
\hline \multicolumn{2}{|c|}{ Contempt } \\
\hline Low warmth & Low competence \\
\hline \multicolumn{2}{|c|}{ Envy } \\
\hline Low warmth & High competence \\
\hline
\end{tabular}

Figure 2. Basic parameters and modalities of the Stereotype Content Model (SCM)

Proponents of the Stereotype Content Model (SCM) $[36 ; 66]$ position these parameters (warmth and competence) as precursors of attitude and behavioural responses to members of an external group [68]. Any group can be stereotyped "positively" by one parameter, "negatively" (unfavourably) - by another [66]. Based on this Stereotype Content Model (SCM), several cross-cultural studies have been implemented to study cultural stereotypes of older people's perception in modern societies [36; 49; 66]. For Example, A.J. Cuddy et al [23] diagnosed older people and other age and social groups by measuring warmth and competence, status, and competition in six countries (Belgium, Costa Rica, Hong Kong, Japan, Israel, and South Korea). They found that in all samples, including East Asians, older people were considered low-status and uncompetitive. Israelis had a lower ageist attitude compared to respondents from other Western European cultures but their attitudes were similar to those found in Northern Europe. Another American study also showed the prevalence and generality of ageism in different cultures [53]. Young Americans stereotype older people as warm and incompetent, perceiving them as uncompetitive and low-status people [36]. Numerous cross-cultural data show that older people are perceived in the warmth-competence spectrum as people with a high level of warmth (i.e. socially sensitive and moral) but with a low level of competence [56; 67; 69]. Classical meta-analysis by Kite et al. has shown that when compared with younger people, older people are considered not only less competent but also cause more negative behavioural intentions and assessments [65]. The Stereotype Content Model (SCM) was also one of the two methodological concepts of the mentioned fourth round of European
Social Research (ESS) (2008-2009) [49]. This study measured two indicators: (1) competence and cordiality; (2) experience of age discrimination. The authors generally confirmed that older people are perceived as lower in status [49]. Based on a theoretical and empirical analysis of the most common cross-cultural stereotypes about older people, which contains a mixture of "incompetent but warm", A.J. Cuddy and co-authors suggested that negative images of older people are a general cultural phenomenon. Based on large-scale cross-cultural data, the authors showed the cross-cultural nature of strong negative biases usually associated with older people [36]. Regarding the impact of stereotypes on older people, researchers note that the combination of low competence with high warmth (the "pity" model) corresponds to the "pseudo-positive" habits of older people [70] and, therefore, creates a paternalistic stereotype that does not allow them to take responsibility for their lives $[36 ; 66]$.

\section{CONCLUSIONS}

The study has established that in global trends that are closely related to the ageing of the population, there are emerging problems of gerontological ageism, age discrimination against the elderly, the perception of old age as a period of negative age transformations, etc. It has been substantiated that since the middle of the $20^{\text {th }}$ century, ageism and related phenomena (age stereotypes, discriminatory practices) have been the subject of study at the interpersonal, intergroup, institutional, cultural levels but the terminological field of the concept of "gerontoageism" is still blurred, in modern science there is no clear conceptual basis for this phenomenon, therefore, it is important to 
check and compare research results. Analysis of cross-cultural studies that have been conducted in western and eastern, individualistic and collectivist cultures has shown conflicting results. On the one hand, the attitude towards older people in individualistic countries is more negative than in collectivist ones, on the other hand, there are facts of the absence of considerable differences in the level of gerontoageism between individualistic and collectivist cultures. In both Western and Eastern countries, respondents stereotype older people as "warm" and "incompetent", perceiving them as uncompetitively capable and people of low status. According to most researchers, gerontological ageism and negative orientation towards older people are pan-cultural and persistent. Gerontoageism as a form of age discrimination seems to be a universal phenomenon and in most countries of the world manifests itself in an intolerant attitude towards the elderly by representatives of other age groups, in discriminatory practices in interpersonal interaction, in negative age stereotypes of old age and ageing, etc. Ageism as discrimination based on age can affect social relations, health and well-being of the population of all countries of the world, and, in particular, Ukrainian society in various ways. The results and conclusions obtained in the study are designed to identify opportunities for changing negative perceptions or stigmatising ageing, which will eventually affect everyone.

\section{REFERENCES}

[1] Miklyayeva, A.V. (2009). Age discrimination as a socio-psychological phenomenon. St. Petersburg: Rech.

[2] Ayalon, L., \& Tesch-Römer, C. (Eds.). (2018). Contemporary perspectives on ageism. Berlin: Springer.

[3] Caradec, V. (2012). Sociology of old age and aging. Domains and approaches ( $3^{\text {nd }}$ ed.). Paris: Armand Colin.

[4] Höpflinger, F., Bayer-Oglesby, L., \& Zumbrunn, A. (2011). Dependence of the elderly and long-term care. Updated scenarios for Switzerland. Bern: Editions Hans Huber.

[5] Tholomier, A. (2017). Living and surviving to old age: Challenges of social and health inequalities within the generations that have crossed the $20^{\text {th }}$ century (Doctoral dissertation, University of Geneva, Geneva, Switzerland).

[6] Langevin, A. (1996). Feminine aging and woman's literature. Cahiers du GEDISST, 15, 49-66.

[7] Henrard, J.-C. (2006). Aging and old age: Ideas received, new ideas. Santé, Société et Solidarité, 1, 13-15.

[8] Palmore, E.B. (2017). Auto-gerontology: A personal Odyssey. Journal of Applied Gerontology, 36(11), $1295-1305$.

[9] Senay, V. (2015). Losses related to aging and recourse to abandonment (Masters thesis, Université du Québec à Montréal, Montreal, Canada).

[10] Baeriswyl, M. (2016). Social participation and roles at retirement age: An analysis of developments and issues around social participation and gender relations (Doctoral thesis, University of Geneva, Geneva, Switzerland).

[11] Smirnova, T.V. (2008). Elderly persons: Stereotyped image and social distance. Sociological Studies, 8, 49-55.

[12] Tukumtsev, B.G., \& Yusupova, O.V. (2002). The attitude of young people towards the elderly. Psikhologiya Zrelosti i Stareniya, 3(19), 122-135.

[13] Yadova, M.A. (2020). Russian youth on old age and older people: Spectre of opinions and assessments. Social Sciences and Humanities. Domestic and Foreign Literature. Series 11. Sociology, 1, 34-40.

[14] Berezina, O. (2008). Ageism in society: Problems of late age. Psychological Theory and Learning Technology. Current Problems of Psychology, 8(5). Retrieved from https://www.newlearning.org.ua/sites/default/files/praci/zbirnyk-2008/1.htm.

[15] Poznanska, K. (2018). The social situation of the elderly people and the relationship between old age in the Ukrainian society with the eyes of youth. Visnyk of V.N. Karazin Kharkiv National University. Series "Sociological Studies of Contemporary Society: Methodology, Theory, Methods", 39, 340-345.

[16] Shamne, A.V. (2011). Psychological characteristics of the tolerant/intolerant attitude of the young generation of Ukrainians to the elderly and old age. Egzystencjalne Problemy Człowieka w Okresie Starzenia Się, 1(3), 263-278.

[17] Pecherytsia, N.M. (2018). Ageism among young students and social and pedagogical ways to overcome it. Pedagogical Sciences, 82(2), 216-220.

[18] Yekimova, M.O. (2014). The problem of ageism definition in modern sociology. Bulletin of Kharkiv National University of Internal Affairs, 4, 217-224.

[19] Van den Heuvel, W.J., \& Van Santvoort, M.M. (2011). Experienced discrimination amongst European old citizens. European Journal of Ageing, 8(4), 291-299.

[20] Palmore, E. (1999). Ageism: Negative and positive ( $2^{\text {nd }}$ ed.). New York: Springer Publishing Company.

[21] Butler, R.N. (1969). Age-ism: Another form of bigotry. Gerontologist, 9(4), 243-246.

[22] Traxler, A.J. (1980). Let's get gerontologised: Developing a sensitivity to ageing. The multipurpose senior centre concept. Edwardsville: Southern Illinois University at Edwardsville.

[23] Cuddy, A.J., Fiske, S.T., \& Glick, P. (2004). When professionals become mothers, warmth doesn't cut the ice. Journal of Social Issues, 60(4), 701-718.

[24] Raymer, M., Reed, M., Spiegel, M., \& Purvanova, R.K. (2017). An examination of generational stereotypes as a path towards reverse ageism. The Psychologist-Manager Journal, 20(3), 148-175.

[25] Macia, E., Chapuis-Lucciani, N., \& Boëtch, G. (2007). Age stereotypes, self-esteem and self-rated health. Sciences Sociales et Santé, 25(3), 79-106. 
[26] Nosek, B.A., Smyth, F.L., Hansen, J.J., Devos, T., Lindner, N.M., Ranganath, K.A., Smith, C.T., Olson, K.R., Chugh, D., Banaji, M.R., \& Greenwald, A.G. (2007). Pervasiveness and correlates of implicit attitudes and stereotypes. European Review of Social Psychology, 18, 36-88.

[27] McMullin, J.A., \& Marshall, V.W. (2001). Ageism, age relations, and garment industry work in Montreal. Gerontologist, 41(1), 111-122.

[28] Iversen, T.N., Larsen, L., \& Solem, P.E. (2009). A conceptual analysis of ageism. Nordic Psychology, 61(3), 4-22. doi: 10.1027/1901-2276.61.3.4.

[29] Hoyer, W.J., \& Roodin, P. (2008). Adult development and aging (6 $6^{\text {th }}$ ed.). New York: McGraw-Hill.

[30] Butler, R.N. (1980). Ageism: A foreword. Journal of Social Issues, 36(2), 8-11.

[31] Aaronson, B.S. (1966). Personality stereotypes of aging. Journal of Gerontology, 21(3), 458-462.

[32] Hawkins, M.J. (1996). College students' attitudes toward elderly persons. Educational Gerontology, 22(3), $271-279$.

[33] Linberts, J., \& June, A. (2006). Ageism: Lack of implicit stereotypes across adulthood. Oshkosh Scholar, 1, 83-94.

[34] Gorodova, T.V., \& Kolpina, L.V. (2015). Theoretical bases of gerontological ageism research. Modern Problems of Science and Education, 1(1), 1439-1446.

[35] Horetska, O. (2017). Gerontopsychology. Kharkiv: Vydavnytstvo Ivanchenka I.S.

[36] Cuddy, A.J.C., Norton, M.I., \& Fiske, S.T. (2005). This old stereotype: The pervasiveness and persistence of the elderly stereotype. Journal of Social Issues, 61(2), 267-285.

[37] McKinnon, M.E., Gien, L., \& Durst, D. (2001). Silent pain: Social isolation of the elderly Chinese in Canada. In I. Chi, N.E. Chappell, \& J. Lubben (Eds.), Elderly Chinese in Pacific Rim Countries: Social support and integration (pp. 1-15). Hong Kong: Hong Kong University Press.

[38] Wearing, B. (1995). Leisure and resistance in an ageing society. Leisure Studies, 14(4), 263-279.

[39] Boduroglu, A., Yoon, C., Luo, T., \& Park, D.C. (2006). Age-related stereotypes: A comparison of American and Chinese cultures. Gerontology, 52(5), 324-333.

[40] Calo, T.J., Patterson, M.M., \& Decker, W.H. (2013). Employee perceptions of older workers' motivation in business, academia, and government. International Journal of Business and Social Science, 4(2). Retrieved from https://ijbssnet. com/journal/index/1784.

[41] Gayle, V., McParland, P., Devine, P., \& Innes, A. (2012). Dementia knowledge and attitudes of the general public in Northern Ireland: An analysis of national survey data. International Psychogeriatrics, 24(10), 1600-1613.

[42] Moniz-Cook, E. (2008). Early psychosocial interventions in dementia: Evidence-based practice ( $1^{\text {st }}$ ed.). London: Jessica Kingsley Publishers.

[43] Prince, M., Acosta, D., Ferri, C.P., Guerra, M., Huang, Y., Jacob, K.S., Jotheeswaran, A.T., Liu, Z., Rodriguez, J.J.L., Salas, A., Sosa, A.L., \& Williams, J.D. (2011). The association between common physical impairments and dementia in low and middle income countries, and, among people with dementia, their association with cognitive function and disability. A 10/66 Dementia Research Group population-based study. International Journal of Geriatric Psychiatry, 26(5), 511-519.

[44] Whitbourne, S.K., \& Sneed, J.R. (2002). The paradox of well-being, identity processes, and stereotype threat: Ageism and its potential relationships to the self in later life. In T.D. Nelson (Ed.), Ageism: Stereotyping and prejudice against older persons (pp. 247-273). Cambridge: The MIT Press.

[45] Hagestad, G.O., \& Uhlenberg, P. (2006). Should we be concerned about age segregation? Research on Aging, 28(6), 638-653.

[46] Dannefer, D., \& Shura, R. (2009). Experience, social structure and later life: Meaning and old age in an aging society. In P. Uhlenberg (Ed.), International handbook of population aging (pp. 747-755). Berlin: Springer.

[47] Jurek, Ł. (2018). Determinants of ageism in healthcare in European countries. In Silver economy in Central and Eastern Europe (pp. 21-28). Luxembourg: Publications Office of the European Union. doi: 10.2759/685036.

[48] Löckenhoff, C.E., De Fruyt, F., Terracciano, A., McCrae, R.R., De Bolle, M., Costa, P.T., Aguilar-Vafaie, M.A., Ahn, C.-K., Ahn, H.-N., Alcalay, L., Allik, J., Avdeyeva, T.V., Barbaranelli, C., Benet-Martinez, V., Blatný, M., Bratko, D., BrunnerSciarra, M., Cain, T.R., Crawford, J.T., Lima, M.P., Ficková, E., Gheorghiu, M., Halberstadt, J., Hřebíčková, M., Jussim, L., Klinkosz, W., Knežević, G., Leibovich de Figueroa, N., Martin, T.A., Marušić, I., Mastor, K.A., Miramontez, D.R., Nakazato, K., Nansubuga, F., Pramila, V.S., Purić, D., Realo, A., Reátegui, N., Rolland, J.-P., Rossier, J., Schmidt, V., Sekowski, A., Shakespeare-Finch, J., Shimonaka, Y., Simonetti, F., Siuta, J., Smith, P.B., Szmigielska, B., Wang, L., Yamaguchi, M., \& Yik, M. (2009). Perceptions of aging across 26 cultures and their culture-level associates. Psychology and Aging, 24(4), 941-954.

[49] Seddig, D., Maskileyson, D., \& Davidov, E. (2020). The comparability of measures in the ageism module of the fourth round of the European Social Survey, 2008-2009. Survey Research Methods, 14(4), 351-364.

[50] Xue, B. (2014). Images of ageing in society: A literature review. Journal of Population Ageing, 7(3), $231-253$. doi: 10.1007/s12062-014-9103-X. 
[51] Bratt, C., Abrams, D., Swift, H.J., Vauclair, C.-M., \& Marques, S. (2018). Perceived age discrimination across age in Europe: From an ageing society to a society for all ages. Developmental Psychology, 54(1), 167-180.

[52] Rupp, D.E., Vodanovich, S.J., \& Credé, M. (2005). The multidimensional nature of ageism: Construct validity and group differences. The Journal of Social Psychology, 145(3), 335-362.

[53] Bodner, E., \& Lazar, A. (2008). Ageism among Israeli students: Structure and demographic influences. International Psychogeriatrics, 20(5), 1046-1058.

[54] Xiao, L.D., Shen, J., \& Paterson, J. (2013). Cross-cultural comparison of attitudes and preferences for care of the elderly among Australian and Chinese nursing students. Journal of Transcultural Nursing, 24(4), 408-416.

[55] Hofstede, G., Hofstede, G.J., \& Minkov, M. (2010). Cultures and organizations: Software of the mind ( $3^{\text {nd }}$ ed). New York: McGraw-Hill.

[56] Fiske, S.T., Xu, J., Cuddy, A.C., \& Glick, P. (1999). (Dis)respecting versus (dis)liking: Status and interdependence predict ambivalent stereotypes of competence and warmth. Journal of Social Issues, 55(3), 473-489.

[57] Harwood, J., Giles, H., McCann, R.M., Cai, D., Somera, L.P., Ng, S.H., Gallois, C., \& Noels, K. (2001). Older adults' trait ratings of three age-groups around the Pacific rim. Journal of Cross-Cultural Gerontology, 16(2), 157-171.

[58] Tien-Hyatt, J.L. (1987). Self-perceptions of aging across cultures: Myth or reality? The International Journal of Aging and Human Development, 24(2), 129-148.

[59] Sharps, M.J., Price-Sharps, J.L., \& Hanson, J. (1998). Attitudes of young adults toward older adults: Evidence from the United States and Thailand. Educational Gerontology, 24(7), 655-660.

[60] Koyano, W. (1989). Japanese attitudes toward the elderly: A review of research findings. Journal of Cross-Cultural Gerontology, 4(4), 335-345.

[61] Kim, J.H, Kim, M., Hosoe, Y., \& Ju, K. (2020). Images of older adults among university students: A comparison between Japan and Korea. Journal of Cross-Cultural Gerontology, 35(3), 273-290. doi: 10.1007/s10823-020-09402-y.

[62] Official website of the Eurobarometer. (n.d.). Retrieved from https://data.europa.eu/data/datasets/s2077_83_4_437_ eng?locale=en.

[63] Rychtaříková, J. (2019). Perception of population ageing and age discrimination across EU countries. Population and Economics, 3(4), 1-29.

[64] Arrowsmith, J. (2003). Theories and the practice of age discrimination: Evidence from personnel managers. Review of Employment Topics, 6(1), 1-54.

[65] Kite, M.E., Stockdale, G.D., Whitley, B.E., \& Johnson, B.T. (2005). Attitudes toward younger and older adults: An updated meta-analytic review. Journal of Social Issues, 61(2), 241-266.

[66] Fiske, S.T., Cuddy, A.J.C., Glick, P., \& Xu, J. (2002). A model of (often mixed) stereotype content: Competence and warmth respectively follow from perceived status and competition. Journal of Personality and Social Psychology, 82(6), 878-902.

[67] Heckhausen, J., Dixon, R.A., \& Baltes, P.B. (1989). Gains and losses in development throughout adulthood as perceived by different adult age groups. Developmental Psychology, 25(1), 109-121.

[68] Fowler, C., \& Harwood, J. (2020). Does perceived normativity of intergenerational contact enhance the effects of imagined intergenerational contact? Group Processes \& Intergroup Relations. Retrieved from https://journals. sagepub.com/doi/10.1177/1368430220934548.

[69] Kite, M.E., Deaux, K., \& Miele, M. (1991). Stereotypes of young and old: Does age outweigh gender? Psychology and Aging, 6(1), 19-27.

[70] Nelson, T. (2005). Ageism: Prejudice against our feared future self. Journal of Social Issues, 61(2), 207-221. 


\author{
Анжеліка Володимирівна Коллі-Шамне, Олександр Патапас ${ }^{2}$ \\ ${ }^{1}$ Криворізький державний педагогічний університет \\ 50086, просп. Гагаріна, 54, м. Кривий Ріг, Україна \\ ${ }^{2}$ Університет Миколаса Ромеріса \\ LT-08303, вул. Ateities, 20, м. Вільнюс, Литва
}

\title{
Дискримінація за віком, геронтостереотипи та геронтологічний ейджизм: крос-культурний аспект
}

Анотація. Інтенсивне старіння населення у всіх країнах світу породжує проблеми ейджизму, вікової дискримінації й упередженого ставлення до людей похилого віку, які провокують значні негативні наслідки як для представників цього віку, так і для суспільства загалом. Дослідження крос-культурних аспектів цих явищ суттєво збагачує їхн розуміння та безпосередньо пов'язане з пошуком шляхів їхнього попередження в різних культурних і соціально-економічних умовах. Мета дослідження полягала в теоретичному аналізі проблеми ейзжизму як форми вікової дискримінації людей похилого віку, зокрема іiі крос-культурних чинників, особливостей і наслідків. Використано методи теоретичного та метатеоретичного рівня (діалектичний метод і метод системного аналізу). У дослідженні визначено ключові тенденції, пов’язані з процесом старіння всього населення. З’ясовано поняття «ейджизм» і його зміст, визначено специфіку поняття «геронтологічний ейджизм», його складові, чинники та форми прояву. Розглянуто крос-культурні особливості проявів ейджизму як форми вікової дискримінації людей похилого віку в західних і східних, індивідуалістичних та колективістичних культурах. Для цього проаналізовано міжнародні теоретичні й емпіричні моделі та програми, а також міжкультурні дослідження ейджизму, реалізовані в різних культурних контекстах (у США, Західній і Східній Європі, Східній Азії, країнах Азіатсько-Тихоокеанського регіону тощо). Отримані в дослідженні результати мають практичне значення, оскільки позначають можливості превенції геронтоейджизму в різних країнах і на різних рівнях соціального життя, й насамперед перспективи зміни негативних уявлень та стигматизації старіння в українському суспільстві

Ключові слова: геронтопсихологія, крос-культурна психологія, стереотипи, ейджизм, старість, вікова дискримінація, модель змісту стереотипів, причини геронтоейджизму 